\title{
One text, many stories: The (ir)relevance of reader- response criticism for apocryphal literature in the Septuagint
}

\author{
Author: \\ S. Philip Nolte \\ Affiliation: \\ ${ }^{1}$ School of Ancient \\ Languages, University of the \\ Northwest, Potchefstroom \\ Campus, Potchefstroom, \\ South Africa \\ Correspondence to: \\ Philip Nolte \\ Email: \\ philip.nolte@iburst.co.za \\ Postal address: \\ PO Box 22023, Lyttelton \\ 0140, South Africa

\section{Dates:} \\ Received: 22 May 2011 \\ Accepted: 30 Mar. 2012 \\ Published: 20 July 2012 \\ How to cite this article: \\ Nolte, S.P., 2012, 'One text, \\ many stories: The \\ (ir)relevance of reader- \\ response criticism for \\ apocryphal literature in the \\ Septuagint', HTS Teologiese \\ Studies/Theological Studies \\ 68(1), Art. \#1092, 10 pages. \\ http://dx.doi.org/10.4102/ \\ hts.v68i1.1092
}

(C) 2012. The Authors. Licensee: AOSIS OpenJournals. This work is licensed under the Creative Commons Attribution License.
This article investigated the value of reader-response theory for the reading of apocryphal texts in the Septuagint. The groundbreaking work on reader-response theory developed by Wolfgang Iser in his book The Act of Reading: A Theory of Aesthetic Response, written in 1978 served as the theoretical point of departure. Although the reader-response theory has been scrutinised and criticised heavily during the last three decades, Iser made a very valuable contribution to the reading of literature. My assumption is that religious texts have to be read in the same way as other literature and therefore literary theories such as Iser's can be conducive for responsible interpretation. The article consists of the following parts: introductory remarks on the value of reader-response theory for the interpretation of apocryphal texts; a short overview of reader-response criticism; a discussion and evaluation of three different aspects of Iser's theory, namely 'gaps' in texts, 'asymmetry' between readers and texts and the concept of 'the implied reader'. The findings of the investigation will be given in part five (Findings).

\section{Introduction}

Although it is accepted in literary theory that different readers interpret the same texts differently, the history of literary criticism shows that there has been, and still is, much debate about this issue (Fowler 1991:1-58; Fish 1980; Hendrix 2006:199-228; Iser 1978; Lategan 1992; Tompkins [1980] 1981a; Tyson 2006). The debate relates to questions such as: do texts have or possess meaning; how do readers produce or create meaning when they read texts; is a text a stable or unstable entity; who is the reader; do readers read texts as individuals or as part of larger communities of interpretation; who are the readers in reader-response criticism; is a reader more important than a text, or vice versa?

New Criticism dominated literary studies especially during the years 1940 to 1960 and was rooted in the theoretical assumption of what can be called objective language ${ }^{1}$ (Holub 1984:3, 5, 15-16, 23; Thiselton 2009:24-29; Tyson 2006:135-149; Zima 1999:17-35). New Criticism set itself up against what became known as biographical-historical criticism, which interpreted texts by studying the lives and times of authors, and was the prevailing literary theory during the nineteenth century and the first part of the twentieth century. Exponents of New Criticism focused all their attention 'on the literary work as the sole source of evidence for interpreting it' (Tyson 2006:137). According to New Criticism, to situate meaning in readers' responses to texts is to commit the error of 'affective fallacy', which entails:

a confusion between the poem and its results ... It begins by trying to derive the standard of criticism from the psychological effects of a poem and ends in impressionism and relativism. (Wimsatt \& Beardsley 1949:21, in Tompkins [1980] 1981a:ix)

Affective fallacy is therefore seen as opening a whole array of subjective or psychological interpretations of texts without a so-called 'objective' standard or norm against which such readings can be evaluated.

Over against this viewpoint, reception theory and reader-response theory argue that texts cannot be understood apart from their interaction with readers. Although reception theory or criticism and reader-response theory or criticism share some common traits, there are a few important

1.It can be assumed that academic discourse or language is objective language in the sense that it is not judgmental, personal and emotive, and that it respects the views of others. It is further objective in the sense that it presents rational arguments to substantiate the theories presented. The notion of objective language is seen as part of a positivistic epistemology which argued that 'the object the theories presented. The notion of objective language is seen as part of a positivistic epistemology which argued that 'the object \& Kunne-lbsch [1977] 1979:136). This view of the relationship between researcher and research material is no longer valid. The term $\&$ Kunne-lbsch [1977] 1979:136). This view of the relationship between researcher and research material is no longer valid. The term
'objective' does not rule out the personal presuppositions and prejudices of writers and readers. All language and research is subjective 'objective' does not rule out the personal presuppositions and prejudices of writers and readers. All language and research is subjective
in the sense that it is used and performed by real, living people who experience emotions and who are historically and socio-culturally situated. 
differences between them as well. ${ }^{2}$ The differences between and commonalities of the two theories (Holub 1984:xii-xiv; Lategan 2009:458) can be summarised as follows:

Reception theory is a coherent and collective movement in a European context, while reader-response criticism is more prevalent in North America and accommodates a wide variety of techniques and methods. The common denominator is a shift of attention from the author of a text and 'the text' itself, to attention on the interaction(s) between texts and readers.

Susan Suleiman and Inge Crosman (1980) distinguish between the following approaches in the field of readerresponse criticism:

1. rhetorical criticism

2. psychoanalytic and subjective studies

3. semiotic and structural criticism

4. phenomenological studies

5. hermeneutics and

6. sociological and historical criticism.

In spite of different perspectives, scholars (see Holub 1984:13-52; Lategan 2009:458-459; Zima 1999:49-56) agree on at least three developments that had an important influence on the birth and further growth of reception theory and reader-response criticism, namely:

1. Sociology of literature which argues that not only the production or the inherent qualities of a work of art is worthy of investigation, but also its effect on society.

2. The concept of the effective history (Wirkungsgeschichte) of a text as it was developed by Hans-Georg Gadamer ([1975] 1979) shows that individual readers do not exhaust the meaning potential of texts, but that different readings complement each other. These different readings form a history which becomes part of potential meanings of texts and they influence ensuing readings.

3. The work of the so-called Prague structuralists. These scholars maintain a firm distinction between the text as stable structure and the realisation of the text by the reader. However, they argue that in the mediation between text and reader the social dimensions of reception become clear.

Robert Fowler (1991:1) touches on these issues when he states that scholars discuss their own experiences of reading texts (Mark's Gospel in Fowler's book) under the guise of the intention of texts, the theological meaning or truth of biblical texts, or the literary structure of texts, to name but a few. My opinion is that a shift away from a focus on texts per se to a focus on our reading experiences of texts can be conducive to gain insight into ourselves and others, and can lead to the creation of transparent dialogues about our prejudices, expectations and preconceptions. Fowler (1991) formulates this possibility as follows:

we shall not only understand what we have been doing all along as we were reading and talking about our reading but also gain new sensitivities that should enable us to read in new ways and gain new insights. (p. 1)

From the vantage point of reader-response theory and reception theory the question is not so much what a text is,

2.See Robert Holub (1984:1-52) for a comprehensive overview of the shifts in paradigms and social and cultural developments that gave rise to the birth and growth of reception theory and reader-response criticism. but more importantly what a text does. Meaning is therefore taken away from the text as a material object or construct and transferred to the area of the reading and reception process (Zima 1999:56). Texts are no longer viewed as monosemic, monolithic and stable structures that convey only one correct meaning as in New Criticism, but as aesthetic objects embedded in an ongoing process of reading, re-reading, reinterpretation and re-adaptation of the social values of people in different life situations. Texts are prone to multilayered interpretations and the concept of one, homogeneous meaning is seriously questioned. Authors do not have any control over their texts after publication, or posting on the Internet. Texts come to life, as it were, when people start reading them and can be interpreted quite differently from what authors intended them to be. Reader-response criticism and reception theory rest upon the assumption that texts have to be read to come to life and to have meaning. Otherwise they are only dried ink on paper, or symbols on computer screens.

This article will give an overview of the following aspects of Wolgang Iser's theory of reader-response criticism: the aesthetic response, gaps in texts and the implied reader. I will evaluate the possibilities of these concepts for reading apocryphal texts in the Septuagint. The investigation consists of four parts. Part one (Introduction) is a general introduction of some of the reasons why I think an investigation of the possibilities of reader-response theory and reception theory may be valuable for the reading of apocryphal texts. Part two (Problem statement) presents the problem which gave rise to this study. A short overview of reader-response criticism will be presented in part three (Reader-response criticism). In part four (Wolfgang Iser) different aspects of Iser's theory will be discussed. The findings of the investigation will be given in part five (Findings).

\section{Problem statement}

The research question I want to address in this article is not so much the value of reading religious texts in the same way as other texts. Developments in biblical studies over the last century made that clear and an obvious conclusion. Rather, what stimulated the research is the fact that in spite of developments in literary theory and the value these entail for biblical studies, it is clear that some commentators of apocryphal texts still interpret those texts without taking their own paradigms seriously enough. A short overview of a number of interpretations of the story of Susanna (an addition to the book of Daniel in the Greek translation of the Hebrew Bible, the Septuagint) will illustrate the case in point. These interpretations are found in the commentaries of George Nickelsburg (1981), Daniel Harrington (1999) and David deSilva ([2002] 2004) as examples. Nickelsburg (1981:1-7), Harrington (1999:1-9) and deSilva ([2002] 2004:15-62) formulate a few important issues that they take into account when reading the apocrypha, which could be summarised as follows:

- Literature is rooted in and affected by historical circumstances.

- Theological conceptions do not arise in a vacuum but in response to historical circumstances and events. 
- The time gap between us and the apocryphal literature means that we read and interpret the texts from perspectives that are filled and compounded by our own prejudices and tastes.

- The theme that as it were, glues the corpus of literature together is a setting of persecution, oppression and loneliness of communities living in an alien environment.

- It is important to read the texts on two levels, namely as literature which entails taking into consideration matters such as genre, structure or plot and the like. Secondly it is also important to read the texts as history within their historical contexts.

Although these insights are valid, they also present the framework in which interpretation of the texts is conducted. Any framework immediately rules out questions and problems which are part of other frameworks. I do not differ with the theoretical perspectives of the three scholars, neither do I want to suggest that their work is not of great value. I merely want to point out that any theoretical framework represents the subjective viewpoint of the interpreter and prematurely determines his or her interpretation. Therefore Nickelsburg (1981), Harrington (1999) and deSilva ([2002] 2004) never move beyond what may be called a 'traditional' interpretation of Susanna, which stresses the evil disposition and behaviour of the elders, Susanna's bravery, Daniel's wisdom and God's justice. For example, they do not address questions such as:

- Why is Susanna a story about a woman, but it ends with glorifying a male?

- What symbolic role does Babylon really play? Is the implication that the community has to be aware of the evil influences of their arch-enemy? Or is it meant to make Babylon the scapegoat for corruption amongst leaders in the community? In other words, the reigning social or cultural system in the Jewish community is not being questioned, but rather some external threat. Such a view would create and maintain a blind spot within the community for a social system which may be conducive to wicked behaviour.

- Why is a non-descript youth the hero in the story? Why is Susanna not a heroic figure in the same manner as Judith? Is it because the threat against Susanna comes from within the Jewish community and not from without? In other words, can women act decisively on their own against Israel's outside enemies but not against the threat (the patriarchal hierarchy) in their own cultural system?

- An issue related to the previous one is: why did God not intervene on Susanna's behalf in the same way as God did with Daniel and his friends in Daniel 3 and 6? In those instances God did not need a male intermediary to rescue God's favourites. On the contrary, God acted directly on their behalf. I am of the opinion that Susanna's story has to be read differently from the tradition of Daniel 3 and 6 . Because her story is set within the Jewish community she could not act in the same way as Judith did and God had to make use of a male Jewish vindicator. The social system of patriarchal dominance in the Jewish community of the time did not allow God to intervene directly on Susanna's behalf, as was the case in Daniel 3 and 6.
Neither Harrington (1999) nor deSilva ([2002] 2004) refer to and/or discuss relevant publications on reading Susanna nor anthropology and social systems (see Bal 1993; Bechtel 1991; Berger [1967] 1990; Bohn 2001; Countryman 1988; Glancy 1993; Levine 1995; Malina 2001; Malina \& Rohrbaugh 1992; Malina \& Neyrey 1991; Sered \& Cooper 1996). The publications mentioned here not only present other perspectives on reading religious literature, but also illustrate the way in which a reader's gender influences their interpretation of Susanna. The gap I encounter when reading Nickelsburg (1981), Harrington (1999) and deSilva ([2002] 2004) is that they do not take their own social and cultural standing or their gender into account when interpreting Susanna. Therefore they get stuck in a one-dimensional reading of the story. The underlying theoretical (undisclosed) assumption is that a socalled objective interpretation of Susanna is possible as long as one reads it in a sympathetic way as literature in its own historical context. However, objective interpretations of texts are not possible because of the role of our own contexts in the interpretation process. Although the way in which our contexts influence our reading of texts may be seen as passé in literary theory, it is still valid to evaluate commentaries and other publications on apocryphal literature that do not reflect this insight. I am of the opinion that taking note of Iser's theories on reader-response criticism can add value to further studies.

\section{Reader-response criticism}

Iser (1978:ix, footnote 1) has certain reservations relating to the translation of the German concept Wirkung into English. The English words 'effect' and 'response' do not precisely convey the range of the German word, which comprises both effect and response. Iser eventually decides to use the word 'response'. Robert Holub (1984:xi-xiii) gives a valuable overview of the conceptual as well as geographical differences between relevant concepts such as Wirkungsgeschichte [effective history], Rezeptionsgeschichte [history of reception], Rezeptionsästhetik [aesthetics of reception], reception theory and reader-response criticism. See also Elizabeth Freund (1987:135) for a discussion of the distinction between Rezeption and Wirkung.

Texts can be dangerous devices and constructs. They can create the illusion of power and truth. Religious texts can be dangerous, because they are frequently used to manipulate, marginalise and do harm to people. On the other hand, texts, especially religious texts, can be liberating when used in responsible and ethical ways. I will aim to argue in favour of constructive, ethical ways to read texts - ways that are conducive for constructive development and transformation of individuals and communities. When people read texts, they realise the potential effects of those texts in the reading process (Iser 1978:ix). The act of realising the potential of texts gives rise to certain reactions in readers. Readers may experience emotions such as joy, revulsion, awe or anger. The reading process may also lead to change in or reinforcement of behaviour, as well as inner healing. Readers may even choose to read only texts that substantiate their 
own ideologies and prejudices, or they may read texts that deliberately challenge their views.

It is important to reflect on the way in which texts and readers interact, especially religious texts, because religious texts communicate with people on a level that touches their deepest convictions and values. Therefore, the development and utilisation of theories and methods that are beneficial for ethical readings of religious texts are constantly in our focus. My view dovetails with the following remarks of Jane Tompkins ([1980] 1981b):

Relocating meaning first in the reader's self and then in the strategies that constitute it, they [later reader-response critics] assert that meaning is a consequence of being in a particular situation in the world. The net result of this epistemological revolution is to repoliticize literature and literary criticism. When discourse is responsible for reality and not merely a reflection of it, then whose discourse prevails makes all the difference. (p. xxv)

My viewpoint is that realities are not predetermined worlds in which every life form on earth exists passively. Human beings participate in constructing their own realities in creative or destructive ways. Literary texts are part of this interaction between people and their different worlds. Texts are not just reflections of reality. Texts challenge, deconstruct, inform, confirm and are constitutive in creating reality. A relevant example in the South African society is the way in which history textbooks for White primary and secondary schools were constructed under the apartheid regime. In these books or texts the roles played by 'non-White' people in the development of the South African society were mostly ignored. ${ }^{3}$ There are at least four issues at stake when reflecting on how texts can be read and how they function in societies, namely:

- Who is responsible for the production of texts? The issue here is not so much institutions such as printing and publishing companies, but rather the communities and individuals creating those texts.

- Who are the texts created for? In other words - who is or are the audience or audiences? Audiences can range from social and/or economical elite, to marginalised groups, to reading communities that have the necessary knowledge and skills for reading and interpreting certain texts. Of course, many more audiences exist.

- For what purposes are texts produced? This question takes into consideration the different agendas and ideologies of the communities by and for whom texts are produced.

- In the case of religious texts, I also ask if those texts do harm to people, or do they facilitate healing in people? Marxist, feminist, gay and postcolonial readings of biblical texts are examples of how communities try to come to grips with religious texts that have formerly marginalised and harmed groups and individuals.

In her discussion of the view on and the role of readers in the interpretation of literature in the 'Classical period' Tompkins ([1980] 1981c:202-206) shows how, in the writings of Longinus (On the Sublime), Plato (The Republic), and Aristophanes (The

3.For a wide variety of discussions and perspectives on the relevance of reader response theory for the South African society, see Lategan (1992).
Frogs), different agendas play a determining role in who was permitted to produce texts. Lyric and epic poets, for example, were seen as dangerous to the state according to Plato and Aristophanes, because of the political potential and force of poetics. The reason for this is that during the Classical Greek period language was perceived as a medium for generating certain kinds of behaviour (see e.g. Longinus, On the sublime $X X V: 2-3)$. The desired effect of literature was to move readers or hearers to active participation, in other words, to action or behaviour.

From the perspective of postmodern philosophy, JeanFrancois Lyotard ([1979] 1984) discusses the power and function of what he calls 'grand narratives' or 'metanarratives' in societies. Lyotard's report can be viewed as a twentieth century portrayal of the 'danger' of local or small narratives to grand or metanarratives that are operative in the world of science and technology. But whereas Plato was negative about the value of small or local narratives (the poets) in society, Lyotard is positive about the constructive role of such narratives. In a very particular sense, I am of the opinion that reader-response criticism can be placed philosophically and epistemologically within the realm of a postmodern philosophy of knowledge. The reason for this can be found in the following words of Lyotard (1984 emphasis in text):

Simplifying to the extreme, I define postmodern as incredulity toward metanarratives ... It [the narrative function] is being dispersed in clouds of narrative language elements ... Conveyed within each cloud are pragmatic valencies specific to its kind. Each of us lives at the intersection of many of these. (p. xxiv)

Postmodern epistemology focuses our attention on the insight that we are constantly interacting in a world of different and divergent 'language games' (Lyotard [1979] 1984:xxiv), as well as the importance of 'local determinism' (Lyotard [1979] 1984:xxiv). Although Iser does not discuss issues such as grand narratives, metanarratives, language games or local determinism, reader-response criticism's insistence on the validity of individual readings of texts over against homogeneous readings found in New Criticism fits the framework of different language games and local determinism. This will become clear as my discussion in the article unfolds.

\section{Wolfgang Iser}

Wolfgang Iser starts the 'preface' to his influential work on reader-response theory, The act of reading: A theory of aesthetic response (1978:ix) as follows: 'As a literary text can only produce a response when it is read, it is virtually impossible to describe this response without also analysing the reading process.'

This formulation leads to two focal points in Iser's discussion, namely the text and the reader. Iser is of the opinion that the text has to be viewed as an entity that contains reading instructions which guide the reader in the reading process. The following paragraphs present a concise overview of the topics of Iser's theory that are important for our investigation, namely: aesthetic response; gaps in texts; implied reader. 


\section{The aesthetic response}

It is largely taken for granted that texts could only have meaning when they are read. However, what is not always taken into consideration is that the reading of texts is not an endeavour where readers are passively observing a selfcontained entity from which meaning can be extracted by making use of so-called right tools. The different ways in which the Bible is read by different Christian communities or denominations is a case in point. Some Christian communities read biblical texts as the unfailing Word of God', which entails that the Bible was inspired by God and therefore is 'the truth', which also means that the Bible is the only truth about God. Such presuppositions about the Bible lead to what is called a fundamentalistic interpretation of Biblical passages, which means that events described in such passages are literally true. The 'right tools' in these kinds of readings are inter alia structural analyses of texts, relating different passages in different books in the Bible to one another regardless of the differences in contexts, as well as anachronistic interpretations of texts. One example of such a reading is the view that the creation narratives in Genesis 1 and 2 are literally true descriptions of how the whole cosmos was created by God.

Fundamentalistic readings of texts flow from the preconception that texts are factual descriptions of reality, and that any language act is an objective description of what language users perceive. This kind of reading does not pertain to religious texts alone, but is found in a wide variety of discourses. An interesting, but also very disturbing example, is the political debate of a few years ago on the treatment of people with HIV and AIDS in South Africa. The Minister of Health and the President of South Africa during that time both read their preferred texts on this issue in such a fundamentalistic way that antiretroviral medicine was not freely available to patients suffering from HIV and AIDS. Their narratives on the matter became metanarratives which overrode other scientific narratives as well as the narratives of the civil organisation ('small narratives'), the Treatment Action Campaign, who argued against their convictions pertaining to this matter. Therefore they chose not to take relevant research into consideration when they addressed the issue.

Reading is an interactive process between texts and readers and is always influenced by our preconceptions and presuppositions. Iser's view on texts forms part of a phenomenological theory of art according to which the study of a literary work should concern not only the text but also, and in equal measure, the actions involved in responding to that text' (Iser 1978:20-21). Iser's philosophical and theoretical forerunner is the Polish theoretician Roman Ingarden, who developed his literary theories along the contours of the phenomenological philosopher, Edmund Husserl. Iser differs from Ingarden's approach in the sense that he takes the active part and the socio-historical dimensions of readers' readings of literary texts into account.
The interaction between texts and readers is the virtual space where meaning is generated by readers. Readers are therefore responsible for their own production of the meanings of texts through a process of 'concretization' (Iser 1978:21). Texts do not have only one meaning applicable to all people at all times and in all cultures. Every time readers read texts they construct their own meanings, which grow from their particular and specific cultural, historical, political, social and religious contexts. Add to this each individual's personality type, emotional and psychological make-up, gender, sexual orientation and life story, and the reading of texts becomes a complex venture.

Iser (1978:21) claims that when we read texts we have to take two aspects of the text into consideration, namely the 'artistic' and the 'aesthetic'. The former has to do with texts created by authors and the second pertains to the realisation of texts by readers, which leads to the view in reader-response theory that texts cannot be understood apart from their results or effects, in other words, apart from being read and interpreted by actual, real readers. One of the consequences of this point of view is that meaning is always a consequence of the particular readings of particular people in particular situations in the world. The variety of interpretations of the apocryphal narrative of Susanna will illustrate this phenomenon. It is in this respect that Iser (1978:21) differentiates between the 'text' and the 'work'. The 'work' is a reader's realisation of a text; therefore it is not identical with the text or with the reader's subjectivity, but takes place in a virtual reality. Virtual reality can be described as a reality existing parallel to the realities presented in texts and the realities of readers. Virtual realities are interfaces between the worlds generated by texts and the worlds and paradigms which form the realities of readers. The work is therefore always more than the text. It is this virtuality (interface) from which the work derives its dynamism (Iser 1978:21). Although this dynamic convergence of text and reader cannot be identified with either the reality of the text or with the reader, traces of both worlds will be visible in the work.

The aesthetic effects of texts cannot be related through referential language, in other words through language which pretends to describe a direct reference between what is described in texts and realities outside of texts. Although Iser maintains that texts contain structures which guide readers through the reading process, he (Iser 1978:22) states that the 'meaning of a literary text is not a definable entity but, if anything, a dynamic experience.' The aesthetic dynamic entails that something is brought into the world that did not exist before. But this existence is a virtual existence, happening on the plane of the creative interaction between text and reader. One of the consequences of this view is that interpreters can create different potential meanings of texts and do not have to restrict themselves to only one meaning. Different readings (meanings) of the same text have to do with what Iser (1978:163-170) calls 'asymmetry between text and reader'. 


\section{Asymmetry and gaps}

Iser (1978:164-170) builds on psychoanalytical research conducted by R.D. Laing, H. Phillipson and A.R. Lee on interpersonal perceptions to describe his notion of gaps and the filling of gaps when readers read texts. In short, Laing, Phillipson and Lee (quoted by Iser 1978) argue that we do not have knowledge of how other people experience us. Therefore we act on account of our own perceptions of how we think others experience us. Another person's experience of me is invisible to me and my experience of that person is invisible to him or her. It is this invisibility or gap which leads to the need to interpret others' experiences of us. Communication between people depends on a continuous filling in of the gaps between people. Laing, Phillipson and Lee (quoted by Iser 1978:165) study the products of this 'filling-in' process and distinguish between the factors of pure perception, projected phantasies and interpretation. Interpersonal relationships are damaged to the degree in which people fill the gaps with their projected phantasies. It is important to realise that 'pure perception' is not possible because 'the dyadic and dynamic interaction comes about only because we are unable to experience how we experience one another, which in turn proves to be a propellant to interaction' (Iser 1978:165 emphasis in text). The limitations which become visible during interaction between people lead to attempts to overcome them, and this can be called interpretation.

According to Iser (1978:167-168) a major difference in the interaction between people and reader-text interaction is that the reading of texts presents no face-to-face situation where one can test one's perceptions and experiences by asking questions. In a way similar to the process of the filling of gaps in interpersonal perception and experience, it is the lack of symmetry between text and reader, the gaps, that gives rise to communication and leads to a filling of gaps in the reading process. Communication between text and reader is an activity that takes place in the imagination of the reader. According to Iser (1978:167-168) this creative and dynamic process is controlled by the text, not as much by what is being said, but rather by what is not said. It is the unsaid, that which is not in the text, the gaps that activate a thought process which can lead to a variety of possible meanings for the text under consideration. Iser (1978) formulates this as follows:

What is missing ... is what stimulates the reader into filling the blanks with projections. He is drawn into the events and made to supply what is meant from what is not said. What is said only appears to take on significance as a reference to what is not said; it is the implications [author's own emphasis] and not the statements that give shape and weight to the meaning. (p. 168)

Consideration of this insight leads to a variety of possibilities for the reading of the story of Susanna. For example, one of the gaps in the story that needs to be considered and reflected upon is the question why Susanna could not defend herself against the evil plans of the elders, but God had to send a male figure in the person of Daniel to rescue her. What is said in the story, gets a clearer relief when one considers what is not narrated, for example how patriarchal values of the time govern the content and flow of the story and how the story promotes and maintains a specific social order by implicating that it is God's will.

To take issues like these into consideration is not the same as reading Susanna in an anachronistic way, namely to ignore social and cultural values of the time in which the story was set and to present relevant (modern or postmodern) questions to the story. It is precisely because our culture differs in many respects from the one described in the story that we (have to) read the narrative from our particular perspective and reflect on how the story can be meaningful for the time we live in. As Iser (1978) says:

They [the gaps in the text] cannot, of course, be filled in by the system [the text] itself, and so it follows that they can only be filled in by another system. Whenever the reader bridges the gaps, communication begins. (p. 169)

I argue that the 'system' that fills in the gaps is the paradigm from which a reader bridges the gaps and interprets the text. Elizabeth Freund (1987:142) calls this paradigm the 'disposition' of the reader.

One of the main objections to a reader-response theory, to a 'filling in of the gaps' according to the reader's paradigm or disposition, is that it sacrifices the 'objectivity' of texts to the subjective arbitrariness of readers. This objection seeks for an ideal norm or standard against which interpretations of texts can be evaluated (Iser 1978:23-24). The problem with this kind of thinking is the question: who decides what the so-called 'ideal norm or standard' is, and on what theories and agendas such decisions are based? What is important to note is that so-called 'objective, ideal norms or standards' are also generated by the subjective readings of the people who develop them. If we want to engage with texts in ethical ways, we have to recognise that the theories, models and methods we utilise for our interpretive endeavours are already theoryladen in the sense that our reading and interpretation are always saturated as it were by conscious and unconscious prejudices and preconceptions. It is by the critical evaluation of Iser's The act of reading by Stanley Fish (1981:2-13) that this problem is put into relief in a very sharp and nuanced way.

The problem Fish addresses in his essay is the question of what is 'determined' and what is 'undetermined' in texts. Iser's determinacy or indeterminacy distinction is indeed one of the most important aspects of his theory. This strength in Iser's theory, however, is also its weakness. Determinacy and indeterminacy - functioning as the two opposite points of an ellipse as it were - present Iser with enough space to move freely between the text as a 'given' and the aesthetic object as 'supplied', '... or, in other words, between what is already given and what must be brought into being by interpretive activity' (Fish 1981:6). I agree with Fish's argument and critique of Iser that the 'brute-fact status of the text' is not a given. The apparently objective and autonomous facts in texts are not given, but are the result of our interpretive activities (see my arguments on 'fundamentalism' above). 
The problem underlying Iser's theory is that he regards the world (external reality) as itself determinate or as something that is given rather than supplied. Fish (1981) describes this dilemma poignantly as follows:

It is only if the world - or 'reality' - is itself a determinate object, an object without gaps that can be grasped immediately, an object that can be perceived rather than read, that indeterminacy can be specified as a special feature of literary experience. Once, however, that move is made, it brings with it a set of interrelated assumptions: the assumption that looking at real objects is different from imagining objects in a poem or novel; the assumption that in the one activity the viewer simply and passively takes in an already formed reality, while in the other he must participate in the construction of a reality; the assumption that knowledge of real people is more direct and immediate than knowledge of characters or lyric speakers; and, finally, the assumption that these two kinds of experience come to us in two kinds of language, one that requires only that we check its structure against the already constituted structure it reproduces or describes, and the other that requires us to produce the objects, events and persons to which it (in a curious, even mysterious, literary way) refers. (p. 8)

These observations also relate to what Iser (1978) says about the difference between 'face-to-face' situations and reading literary texts, because:

the partners in dyadic interaction can ask each other questions in order to ascertain how far their views have controlled contingency, or their images have bridged the gap of inexperienceability of one another's experience. (p. 166)

By this Iser means that in direct communication a real object (subject), namely another person, is present who can act as an empirical check on the turns and twists in the conversation. Apparently, this kind of constraint is not present in fictional literature. Iser (1978:193-195) makes use of the novels of Ivy Compton-Burnett to illustrate his point. However, as Fish (1981:9) argues, although Iser is accurate in his evaluation of conversation in Compton-Burnett, 'it is a perfectly accurate account of conversation in everyday life.' The pragmatic conditions of face-to-face situations do not fix the meanings of the words. People listen to and interpret the words of others in the same way as they do when reading fictional (or non-fictional) literature. We build structures of assumptions that influence all our listening and reading, whether it is so-called direct communication with other people or reading texts. Direct conversation doesn't necessarily mean that every utterance made by partners will be understood as it is intended. After all, who decides what the meaning of an utterance is or should be? It may be the person who makes the utterance, but it may as well be the person who is listening at that moment. One of Iser's (1978:135-139) assumptions that lead to his theory is his distinction between 'perception' and 'ideation'. Iser is of the opinion that our perception of the world we live in differs substantially from our ideation (imaging or imagining) of what we read in texts. However, this kind of distinction becomes problematic when we recognise that our perception of our world or worlds is already the product of an ideation process. So-called 'pure perception' does not exist. All perception is mediated, in other words filtered as it were by our assumptions, prejudices and many more:
To put it another way, mediated access to the world is the only access we ever have; ... What this means is that we know 'real people' no more directly than we know the characters in a novel. (Fish 1981:10)

In the end Fish (1981:11-12) argues that everything, literature as well as the events, objects and people in everyday life, is simultaneously determinate (given) and indeterminate (supplied). It is determinate or given, because all people perceive everything from within a set of assumptions (vantage point, paradigm) that predetermines what could possibly be perceived. These assumptions are also not idiosyncratic to individuals, but are public and communal and therefore interpretation can't be arbitrary. The interpretive community or communities readers belong to constrain their interpretations. Fish (1981) formulates this as follows:

there is no subjectivist element of reading, because the observer is never individual in the sense of unique or private, but is always the product of the categories of understanding that are his by virtue of his membership in a community of interpretation. (p. 11)

On the other hand everything is indeterminate or supplied insofar as everything is produced by the activities of a reader, but immediately one has to recognise that readers are never free. This observation also begs the question of who determines what 'gaps' may or may not be found in texts. It can be argued that readers from different interpretive communities may find different gaps and may supply different ways to interpret texts. If I understand Iser correctly, it seems that he is of the opinion that the gaps in a text are fixed, because it is part of the way in which texts 'lead' readers in the reading process. If this how Iser sees it, I cannot agree with him.

Fish's insights are valuable for the interpretation of religious texts. These kinds of texts do not copy so-called 'objective realities' that already exist but create their own symbolic worlds - they are interpretations of the authors' perceptions of reality. Texts are written from specific vantage points and can therefore not be accepted as 'the truth' about 'reality' as if there is only one truth and one reality. People live in different realities and give expression to their understanding of their realities in different ways. That the story of Susanna created a world of its own in order to communicate certain values to the community it was intended for. It does not mean, however, that readers such as ourselves have to accept that world as our own or even as 'truth'. The value of reading texts lies in the process of engaging in a debate with the worlds presented by these texts. Iser (1978:24) argues that it is this propensity of fictional texts that lends them their indeterminacy and their ability to communicate with readers. If texts were closed systems of reference and meaning they would hardly communicate in meaningful ways to different readers in different times. Open-endedness, gaps and indeterminacy furnish texts with the possibility to have significant effects for people reading them centuries

4.Fish's theory relates to recent developments in epistemology as it is fleshed out as it were in the influential work Philosophy in the Flesh: the embodied mind and a it wallenge to Western thought, by George Lakoff and Mark Johnson (1999). Lakof challenge to Western thought, by George Lakf and Johnson argue that we perceive our world not in an objective, unmediated way, but by making use of our bodies and the ways in which we experience our bodily existence in the world. 
after their creation. The possibility of texts to influence can be seen when the aesthetic effects of texts result in restructuring or reframing people's experiences.

\section{The implied reader}

When arguing from the point of view that readers are not only passive receptionists of already existing truths but are actively involved in a meaning-making process when they read texts, it leads to the question: what kind of readers do we have in mind $?^{5}$ For the purposes of my investigation it is important to differentiate between 'reader' and 'critic', as well as to clarify the concept of 'critical reader'. I will first discuss Iser's concept of the 'implied reader' and thereafter related issues will be argued from different vantage points.

According to Iser (1978) the implied reader is a textual construct that:

embodies all those predispositions necessary for a literary work to exercise its effect - predispositions laid down, not by an empirical outside reality, but by the text itself. Consequently, the implied reader as a concept has its roots firmly planted in the structure of the text; he is a construct in no way to be identified with any real reader. (p. 34)

The rationale underlying Iser's implied reader is that texts must embody certain conditions that facilitate their actualisation by readers. At least one of these conditions is that texts consist of structures that invite readers to respond. The implied reader is one of these structures, inviting readers to play particular roles when reading texts.

Iser (1978:35-36) distinguishes between two interrelated aspects when reflecting on the role of the reader, namely 'the reader's role as a textual structure' and 'the reader's role as a structured act'.

\section{The reader's role as textual structure}

Texts are constructions of worlds as perceived by their authors and offer hints and pointers to the world views underlying authors' stories and/or arguments. These worlds and world views are in more than one way unfamiliar to readers, and therefore they:

have to be placed in a position which enables them to actualise the new view. This position, however, cannot be present in the text itself, as it is the vantage point for visualizing the world represented and so cannot be part of that world. (Iser 1978:35)

The position, or 'standpoint', is put forward by different perspectives in texts from which readers can gain access to the new worlds of authors, namely those of 'the narrator, the characters, the plot, and the fictitious reader' (Iser 1978:35). By reading texts from the vantage points of different perspectives, readers are empowered to gradually move towards an understanding which is more meaningful than reading it from only one perspective. This kind of reading has the possibility to engage readers in a critical dialogue with what they are reading, because they do not read texts

5.See Kevin Vanhoozer (1998:148-195), Walker Gibson (1980:1-6), Gerald Prince (1980:7-25) and Iser (1978:27-34) for an overview of theories on different kinds of readers that have been developed by different scholars. without having their own repertoire of texts, world views and values. Iser (1978:35) is of the opinion that the different perspectives shade into each other gradually and converse on a single meeting place, which he calls the meaning of the text. However, one has to ask what Iser means by 'the meaning of the text'? As Iser (1978) himself argues, and with which I concur, meaning is not monolithic and is created when texts are realised and actualised by readers. It is problematic to talk about 'the' meaning of 'the' text when reading ancient religious texts. We do not have 'the original' manuscripts any longer and we construct the socio-cultural, historical and religious situations in which these texts originated by making use of different collections of data as well as theories, methods and models available to us. My interpretation of a text such as the Susanna narrative is therefore only my interpretation created in 2011 and from a very specific vantage point, namely as white, male, Afrikaans speaking, former pastors in a traditional Afrikaans Reformed church, doing academic research into the possible value of apocryphal literature for our society. My life experiences play an important role in my interpretation of the texts I choose to read.

When Iser (1978) states that standpoint and convergence of perspectives are not presented in or by the text, but that they:

emerge during the reading process, in the course of which the reader's role is to occupy shifting vantage points that are geared to a prestructured activity and to fit the diverse perspectives into a gradually evolving pattern ... (p. 35)

he opens up the possibility that readers' preconceptions and world views could be challenged by the different perspectives they experience during the reading process. This interaction leads to Iser's second aspect, namely the reader's role as a structured act.

\section{The reader's role as a structured act}

The gradual convergence of the different perspectives offered by texts and their final meeting place (meaning) are not linguistically formulated, but have to be imagined, and it is in and through this process of imagining that 'the textual structure of his [the reader's] role begins to affect the reader' (Iser 1978:36). By 'affect' Iser refers to a process during which mental images are formed (also called 'ideational activity') by the reader when reading the text from the different perspectives that the text offers. Affect, mental imagery and ideational activity suggest that readers are actively engaged in making meaning of what they are reading. Meaning making is not a linear movement, though, but can be viewed as a cyclical process during which a variety of mental images are formed which can be replaced or maintained when reading from the different perspectives offered by the text.

The process described thus far creates tension in readers because they can never dissociate themselves from what Iser (1978:37) calls 'the whole repertoire of historical norms and beliefs.' With this statement Iser criticises Wayne Booth's (1963:137 quoted in Iser 1978:36-37) idea that a reader's ideas have to coincide with an author's ideas and world view. Booth is of the opinion that authors create their readers and that understanding of texts is only possible when authors 
and readers find complete agreement. I disagree with this view of passive readers who are not actively and consciously engaging with the texts they read. Readers cannot temporarily or completely suspend their values and beliefs during the reading process. Iser (1978:37) is of the opinion that one can conceptualise 'two selves' in the reading process, namely the role offered by the text and the real reader's own outlook, but the one can never be eclipsed by the other. The two selves will always remain in tension with one another.

It is this tension that makes it possible for readers to engage critically with texts and not merely accept what they read as truth. This tension also makes it possible for ancient texts to still have value centuries after they've been written. To expect of readers to suspend their conceptual and ideological frameworks is to hold onto an outdated idea of objectivity as if readers were free of preconceptions, prejudices, paradigms and frames of reference. At this point in the discussion I utilise Fowler's discussion (1991:27-31) of George Steiner's distinction between 'reader' and 'critic' because I see myself as a critical reader of literary texts. Table 1 presents an overview of the main differences between reader and critic.

Fowler argues that when reader-response critics talk about themselves as readers, those readers can be positioned somewhere along a wide spectrum between two positions coined by Steiner, namely a 'pure (but hypothetical) critic' or 'objectifying pole' and a 'pure (but hypothetical) reader' or 'subjectifying pole' (Fowler 1991:29). Table 2 gives a summary of Fowler's (1991:29-30) suggestions to clear up what he calls 'much equivocation regarding the reader in reader-response criticism' (Fowler 1991:29).

Whether a strict distinction such as the above is possible, is a debatable matter. I am not convinced that categories such as 'pure critic' and 'pure reader' are possible or even conducive for the debate. Even if critics are aware of and do make their critical positions clear, they are never 'purely objective' and 'objectifying' in their reading and interpretation of literary texts. Every reading experience is a subjective one in the sense that no reader, not even a competent literary critic, is able to distance himself or herself from their presuppositions and biases. But every reading is also non-subjective in the sense that readers are always part of interpretive communities (see The reader's role as a structured act above). The best critical readers can do is to be aware of their predispositions and factor those issues into their interpretation of texts, although this does not mean that any reading of a text is a valid one. It is therefore important to be part of critical communities where one's reading experiences can be evaluated by fellow readers.

\section{Findings}

I have shown that apocryphal literature is to be read and studied in the same way as other literature, especially fictional literature. As in texts written by William Shakespeare, Jane Austen, J.M. Coetzee, Nadine Gordimer and André P. Brink, apocryphal texts create worlds of their own. They relate

TABLE 1: The differences between reader and critic.

\begin{tabular}{|c|c|}
\hline Critic & Reader \\
\hline Judge and master of text. & Servant to text. \\
\hline $\begin{array}{l}\text { Steps back from text; takes magisterial } \\
\text { pose of critical and objectifying } \\
\text { distance. }\end{array}$ & $\begin{array}{l}\text { Tries to eliminate distance between } \\
\text { self and text and allows for merging of } \\
\text { own being with text. }\end{array}$ \\
\hline $\begin{array}{l}\text { Criticism by nature adversative, } \\
\text { competitive and even parasitic. }\end{array}$ & $\begin{array}{l}\text { Does not objectify text; finds in text } \\
\text { source of inspiration. Is read by text } \\
\text { - enters into text and is entered into } \\
\text { by text. }\end{array}$ \\
\hline $\begin{array}{l}\text { Makes and declares judgments about } \\
\text { texts. }\end{array}$ & $\begin{array}{l}\text { Does not make judgments about } \\
\text { texts. }\end{array}$ \\
\hline $\begin{array}{l}\text { Evaluates and ranks texts - prescribes } \\
\text { what should be read and what not, thus } \\
\text { creating a canon or 'syllabus'. }\end{array}$ & $\begin{array}{l}\text { Unconsciously accepts texts as part of } \\
\text { canon, and feels self as accountable } \\
\text { to canon. }\end{array}$ \\
\hline
\end{tabular}

TABLE 2: Fowler's distinction between 'pure' critic and 'pure' reader.

Pure critic objectifying pole

Aware of and declares position as critic within critical tradition.

Often elucidates history of criticism of text by observing what has happened in reading experiences of other critics of the particular text.

Goal is to describe reading experiences of other readers/critics, rather than explicating texts. Intention of critic is to comprehend, encompass and rise above critical colleagues.

Sees self as judge and master in relation to texts and peers.

Objectifies the experience of reading within specific tradition of criticism.

Also called 'sociological' or 'ideological'

pole - critics objectify their reading

experiences according to critical

presuppositions or ideology shared with

fellow critics in critical community.

important values in the form of stories. What makes them different from other kinds of fictional literature though is that stories like Susanna, Judith, and the Maccabees texts for example, pretend to narrate religious values and specific views on the so-called 'will of God'. I am of the opinion that literary theory presents us with valid paradigms, epistemology, models and methods to read and evaluate the value of religious texts such as the texts just mentioned.

Under Problem statement I have shown that at least three commentators on Susanna tend to get stuck in a onedimensional interpretation of the story because of their (undisclosed) theoretical point of departure that an objective reading of literature is possible.

I concur with Iser when he says that reading consists of an interaction between readers and texts. As I have argued above, (The reader's role as textual structure) readers do not engage with texts as if they (the readers) are blank pages waiting to be inscribed upon. When readers read, they do so from specific vantage points which have been (in)formed at least by their upbringing, ethnicity, religious background, gender, academic history, cultural values, sexual orientation, psychological disposition, personality types and life stories. For one reader the 'aesthetic work' may be something quite different from what it may be for another. I agree with Fish that the main area of dispute in Iser's theory is Iser's distinction between determinacy and indeterminacy. This distinction shows that Iser tends to sit on two chairs at the 
same time, namely to maintain a certain kind of objectivity for texts as 'given' that constrains readers' interpretation, and simultaneously asserts the freedom of readers to 'supply' their own understanding of the 'gaps' in texts. Although this issue can be debated in more depth, the discussion above (The reader's role as textual structure) illustrates sufficiently why this matter is important.

I have also shown in what way Iser's concept of 'the implied reader' (the implied reader), especially his notions of 'the reader's role as a textual structure' and 'the reader's role as a structured act', contribute to the awareness that we read texts from our own vantage points and perspectives.

The article has argued (albeit in a preliminary way) why the aspects discussed are valuable for the investigation of religious texts such as the apocryphal literature in the Septuagint.

\section{Acknowledgements Competing interest}

The author declares that he has no financial or personal relationship(s) which may have inappropriately influenced him in writing this article.

\section{References}

Bal, M., 1993, 'The elders and Susanna', Biblical Interpretation 1(1), 1-19.

Bechtel, L.N., 1991, 'Shame as sanction of control in biblical Israel: Judicial, political, and social shaming', Journal for the Study of the Old Testament 49, 47-76. http:// dx.doi.org/10.1163/156851593X00377

Berger, P.L., [1967] 1990, The sacred canopy: Elements of a sociological theory of religion, Anchor Books, New York, NY.

Bohn, B., 2001, 'Rape and the gendered gaze: Susanna and the elders in early modern Bologna', Biblical Interpretation 9(3), 259-286. http://dx.doi. org/10.1163/156851501317072710

Countryman, L.W., 1988, Dirt, greed, and sex: sexual ethics in the New Testament and their implications for today, Fortress Press, Philadelphia, PA.

DeSilva, D.A., [2002] 2004, Introducing the apocrypha: message, context, and significance, Baker Academic, Grand Rapids, MI.

Fish, S., 1980, Is there a text in this class? The authority of interpretive communities, Harvard University Press, Cambridge, MA.

Fish, S., 1981, 'Why no one's afraid of Wolfgang Iser', Diacritics 11, 2-13. http://dx.doi. org/10.2307/464889

Fokkema, D.W. \& Kunne-Ibsch, E., [1977] 1979, Theories of literature in the twentiet century. Structuralism, Marxism, aesthetics of reception and semiotics, C Hurst \& Company, London.

Fowler, R.M., 1991, Let the reader understand. Reader-response criticism and the Gospel of Mark, Fortress Press, Minneapolis, MN.

Freund, E., 1987, The return of the reader: Reader-response criticism, Methuen \& Co., London.

Gadamer, H-G., [1975] 1979, Truth and method, Sheed and Ward, London.
Gibson, W., 1980, 'Authors, speakers, readers, and mock-readers', in J.P. Tompkins (ed.), Reader-response criticism: From formalism to post-structuralism, pp. 1-6, (ed.), Reader-response criticism:
Johns Hopkins Press Ltd, London.

Glancy, J.A., 1993, 'The accused: Susanna and her readers', Journal for the Study of the Old Testament 58, 103-116. http://dx.doi.org/10.1177/030908929301805808

Harrington, D.J., 1999, Invitation to the apocrypha, William B. Eerdmans Publishing Company, Grand Rapids, MI.

Hendrix, H., 2006, 'De lezer in de tekst', in K. Brillenburg Wurth \& A. Rigney (reds.), Het leven van teksten: Een inleiding tot de literatuurwetenschap, pp. 199-228, Amsterdam University Press, Amsterdam.

Holub, R.C., 1984, Reception theory: A critical introduction, Methuen, Inc., New York, NY.

Iser, W., 1978, The act of reading: A theory of aesthetic response, Johns Hopkins University Press, Baltimoer, MD.

Iser, W., 1976, Der Akt des Lesens. Theorie ästhetischer Wirkung, Routledge \& Kegan Paul Ltd, Fink, München, London.

Lakoff, G. \& Johnson, M., 1999, Philosophy in the Flesh: The embodied mind and its challenge to Western thought, Basic Books, New York, NY.

Lategan, B., 1992, The reader and beyond: Theory and practice in South African reception studies, HSRC Publishers, Pretoria. (HSRC series in research methodology, 27).

Lategan, B., 2009, 'Reception theory', in A. Du Toit (ed.), Focusing on the message: New Testament hermeneutics, exegesis and methods, pp. 457-484, Protea, Pretoria. (Guide to the New Testament series).

Levine, A-J., 1995, 'Hemmed in on every side: Jews and women in the book of Susanna', in A. Brenner (ed.), A feminist companion to Esther, Judith and Susanna pp. 303-323, Sheffield Academic Press, Sheffield, England. (The Feminist Companion to the Bible, 7).

Lyotard, J-F., [1979] 1984, The postmodern condition: A report on knowledge, Manchester University Press, Manchester.

Malina, B.J., 2001, The New Testament world: Insights from cultural anthropology, (rev. \& expanded edn.), Westminster John Knox Press, Louisville, KY.

Malina, B.J. \& Neyrey, J.H., 1991, 'Honor and shame in Luke-Acts: Pivotal values of the Mediterranean world', in J.H. Neyrey (ed.), The world of Luke-Acts: Models for interpretation, pp. 25-65, Hendrickson, Peabody, MA

Malina, B.J. \& Rohrbaugh, R., 1992, Social science commentary on the Synoptic Gospels, Fortress, Minneapolis, MN.

Nickelsburg, G.W.E., 1981, Jewish literature between the Bible and the Mishnah. A historical and literary introduction, SCM Press, London.

Prince, G., 1980, 'Introduction to the study of the narrate', in J.P. Tompkins (ed.), Reader-response criticism: From formalism to post-structuralism, pp. 7-25, Johns Hopkins Press, London.

Sered, S. \& Cooper, S., 1996, 'Sexuality and social control: Anthropological reflections on the book of Susanna', in E. Spolsky (ed.), The judgment of 'Susanna' - Authority and witness, pp. 43-55, Scholars Press, Atlanta, GA. (Society of Biblical Literature: Early Judaism and its literature, 11).

Suleiman, S.R. \& Crosman, I. (eds.), 1980, The reader in the text: Essays on audience and interpretation, Princeton University Press, Princeton, NJ.

Thiselton, A.C., 2009, Hermeneutics: An introduction, William B. Eerdmans Publishing Company, Grand Rapids, MI.

Tompkins, J.P. (ed.), [1980] 1981a, Reader-response criticism. From formalism to poststructuralism, Johns Hopkins Press, London.

Tompkins, J.P., [1980] 1981b, 'An introduction to reader-response criticism', in J.P. Tompkins (ed.), Reader-response criticism: From formalism to post-structuralism, Johns Hopkins Press Ltd, London.

Tompkins, J.P., [1980] 1981c, 'The reader in history', in J.P. Tompkins (ed.), Readerresponse criticism: From formalism to post-structuralism, Johns Hopkins Press Ltd, London.

Tyson, L., 2006, Critical theory: A user-friendly guide, Routledge, New York, NY.

Vanhoozer, K.J., 1998, Is there a meaning in this text?, Zondervan Publishing House, Grand Rapids, Michigan, MI.

Zima, P.V., 1999, The philosophy of modern literary theory, The Athlone Press, London. 